\title{
Genetic divergence among tomato leafminer populations based on AFLP analysis
}

\author{
Fábio Akiyoshi Suinaga( ${ }^{(1)}$, Vicente Wagner Dias Casali(2), Marcelo Picanço(3) and John Foster ${ }^{(4)}$
}

\begin{abstract}
(1)Embrapa Algodão, Rua São Paulo, 790, CEP 78850-000 Primavera do Leste, MT. E-mail: suinaga@cnpa.embrapa.br (2)Universidade Federal de Viçosa (UFV), Dep. de Fitotecnia, CEP 36571-000 Viçosa, MG. E-mail: casali@ufv.br (3)UFV, Dep. de Biologia Animal, CEP 36571-000 Viçosa, MG. E-mail: picanco@ufv.br (4)University of Nebraska-Lincoln, Dep. of Entomology, 312G Plant Industry, 68583-0816, Lincoln, NE. E-mail: jfoster1@unlnotes.unl.edu
\end{abstract}

\begin{abstract}
The objective of this work was to determine the genetic differences among eight Brazilian populations of the tomato leafminer Tuta absoluta (Meyrick) (Lepidoptera: Gelechiidae), from the states of Espírito Santo (Santa Tereza), Goiás (Goianápolis), Minas Gerais (Uberlândia and Viçosa), Pernambuco (Camocim de São Félix), Rio de Janeiro (São João da Barra) and São Paulo (Paulínia and Sumaré), using the amplified fragment length polymorphism (AFLP) technique. Fifteen combinations of EcoRI and MseI primers were used to assess divergence among populations. The data were analyzed using unweighted pair-group method, based on arithmetic averages (UPGMA) bootstrap analysis and principal coordinate analysis. Using a multilocus approach, these populations were divided in two groups, based on genetic fingerprints. Populations from Goianápolis, Santa Tereza, and Viçosa formed one group. Populations from Camocim de São Félix, Paulínia, São João da Barra, Sumaré, and Uberlândia fitted in the second group. These results were congruent with differences in susceptibility of this insect to insecticides, previously identified by other authors.
\end{abstract}

Index terms: Lycopersicon esculentum, biometry.

\section{Divergência genética entre populações da traça-do-tomateiro baseada em análises de AFLP}

\begin{abstract}
Resumo - O objetivo deste trabalho foi determinar a divergência genética entre oito populações de Tuta absoluta (Meyrick) (Lepidoptera: Gelechiidae), provenientes dos Estados do Espírito Santo (Santa Tereza), Goiás (Goianápolis), Minas Gerais (Uberlândia e Viçosa), Pernambuco (Camocim de São Félix), Rio de Janeiro (São João da Barra) e São Paulo (Paulínia e Sumaré), utilizando a técnica do polimorfismo do comprimento de fragmentos amplificados de DNA (AFLP). Foram utilizadas 15 combinações entre primers EcoRI e MseI, a fim de estimar tal diferença. Os dados foram analisados pelo método da média aritmética não ponderada (UPGMA) e dos componentes principais. Utilizando as informações advindas de diversos lócus, as populações de traça-do-tomateiro de Goianápolis, Santa Tereza e Viçosa formaram um grupo ao passo que as populações advindas de Camocim de São Félix, Paulínia, São João da Barra, Sumaré e Uberlândia formaram outro grupo. Tais resultados foram parcialmente coincidentes com resultados referentes à suscetibilidade deste inseto a inseticidas, relatados por outros autores.
\end{abstract}

Termos para indexação: Lycopersicon esculentum, biometria.

\section{Introduction}

The tomato leafminer, Tuta absoluta (Meyrick) (Lepidoptera: Gelechiidae), is an oligophagous pest which damages eggplants, green peppers, and especially tomatoes. It is one of the most important insect pests of tomato in the Neotropical region, mainly in South America (Picanço et al., 1998). T. absoluta is also a pest of economic importance in Argentina, Bolívia, Brazil, Chile, Colombia, Ecuador, Peru, Uruguay and Venezuela (Picanço et al., 1997).
T. absoluta not only feeds on tomato leaves but also on its stems, apices, flowers, and fruits. In high densities, this insect causes significant leaf damage, resulting in reduced fruit yield. Damage caused by this pest is analogous to that caused by other Gelechiidae tomato pests, such as Keiferia lycopersicella (Wals.) and Phthorimea operculella (Zell.). The former can be found in the Central and North Americas and the latter in Africa, Asia, and Europe as well as in the Americas (Shipp et al., 1998). 
In order to control this pest, farmers perform more than 36 insecticide applications within a single crop cycle. As a consequence, reduced efficiency and control failure of the insecticides used against T. absoluta have been reported in Brazil (Guedes et al., 1994; Siqueira et al., 2000a) and in Chile (Salazar \& Araya, 1997). Siqueira et al. (2000b) showed differences among Brazilian populations of T. absoluta, in susceptibility to abamectin, cartap, methamidophos, and permethrin, which could indicate a development of resistance of this insect to these insecticides as stated by Siqueira et al. (2000a, 2000b). Despite these facts, there has been no investigation of molecular divergence among these populations.

A recently developed technique for assessing molecular differences among populations is the amplified fragment length polymorphisms (AFLP) (Vos et al., 1995). Because of the vast number of loci available, AFLP has a great potential to discover genetic divergence (McMichael \& Prowell, 1999). Besisdes, this technique has demonstrated to be a sensitive and powerful tool to distinguish among genotypes from different geographic origins as well as providing sufficient molecular markers for characterizing insect genomes (Parsons \& Shaw, 2001). Several examples support the use of AFLP for genetic studies of insect populations such as: Spodoptera frugiperda (J.E. Smith) (McMichael \& Prowell, 1999), Lymantria dispar (Linnaeus) (Reineke et al., 1999), and Bemisia tabaci (Gennadius) (Cervera et al., 2000).

The objective of this work was to determine genetic differences among eight populations of Tuta absoluta by the amplified fragment length polymorphism technique.

\section{Material and Methods}

\section{Insect populations}

Eight populations of T. absoluta from the states of Espírito Santo (Santa Tereza), Goiás (Goianápolis), Minas Gerais (Uberlândia and Viçosa), Pernambuco (Camocim de São Félix), Rio de Janeiro (São João da Barra), and São Paulo (Paulínia and Sumaré), Brazil, were used in this study. All populations, except Sumaré, were resistant to abamectin, cartap, methamidophos, and permethrin (Siqueira et al., 2000b). Colonies of T. absoluta were initially established by at least 500 larvae obtained from heavily infested plants, collected at each sampling site from tomato field crops. Each population was reared isolated from the others, on tomato plants of Santa Clara variety, without insecticide exposure, enclosed in cages and maintained in the laboratory and previously tested for resistance to abamectin, cartap, methamidophos, and permethrin by Siqueira et al. (2000b) (Table 1). All samples were composed of $4^{\text {th }}$ instar larvae and were fixed and stored in $70 \%$ ethanol.

\section{DNA isolation}

DNA was extracted from fifteen individual larvae per population, using the entire body, following cetylmethylammonium bromide (CTAB) protocol (Reineke et al., 1998). DNA pellets were dissolved in 20 ì $\mathrm{L}$ of TE buffer and short term stored at $4^{\circ} \mathrm{C}$. The quantity of DNA in each preparation was estimated by electrophoresis of $1 \mathrm{ì} \mathrm{L} \mathrm{of} \mathrm{each} \mathrm{suspension} \mathrm{on} 0.8 \%$ agarose gels containing $0.2 \mathrm{ì} \mathrm{L} / \mathrm{mL}$ of ethidium bromide and then comparing band intensity with known quantities of lambda phage DNA.

\section{AFLP analysis}

Templates for amplified fragment length polymorphism (AFLP) reactions were prepared following Vos et al. (1995), using approximately $200 \mathrm{ng}$ of genomic DNA for restriction digests with the endonucleases EcoRI (Amersham Pharmacia Biotech Inc., Piscataway, NJ, USA) and MseI (New England Biolabs, Beverly, MA, USA) and ligation of adapters (Table 2). The restrictionligation mixtures (RLM) were diluted 1:10 in TE buffer and these products served as templates for further preamplification reactions. The reaction volumes were 25.5 ì L, and composed of 2.5 ì L of RLM, 0.5 ì L of AmpliTaq DNAPolymerase (Applied Biosystems, Foster City, CA, USA), 20 ì L of AFLP Pre-Amp Primer Mix II

Table 1. Origin of Tuta absoluta populations, reared in laboratory, used in this work.

\begin{tabular}{lllc}
\hline Code & County & State & $\begin{array}{c}\text { Insecticide } \\
\text { resistance status }\end{array}$ \\
\hline GO & Goianápolis & Goiás & 2 \\
PA & Paulínea & São Paulo & 3 \\
PE & Camocim de São Félix & Pernambuco & 2 \\
S J & São João da Barra & Rio de Janeiro & 3 \\
ST & Santa Tereza & Espírito Santo & 2 \\
SU & Sumaré & São Paulo & na $^{(2)}$ \\
UB & Uberlândia & Minas Gerais & 2 \\
VC & Viçosa & Minas Gerais & 4 \\
\hline
\end{tabular}

(1)Resistant to at least two, three or four insecticides. ${ }^{(1)}$ Data non available. 
(Life Technologies, Gaithersburg, MD, USA), containing primers E0 and MC (Table 2), and 2.5 ì L of $10 \mathrm{X}$ PCR buffer plus $\mathrm{MgCl}_{2}$ (Applied Biosystems). Polymerase chain reactions (PCRs) amplifications were performed in an applied biosystems 9700 thermalcycler using 20 cycles. Each cycle comprised 30 seconds at $94^{\circ} \mathrm{C}$, 1 minute at $56^{\circ} \mathrm{C}$, and 1 minute at $72^{\circ} \mathrm{C}$. Selective amplifications were done using various combinations of EcoRI and MseI primers, both of them with three selective nucleotides, $\mathrm{E}+3$ and $\mathrm{M}+3$ (Table 2). A total reaction volume (10 ì L) per template-primer set was composed of $2 \grave{i} \mathrm{~L}$ of 1:100 pre-amplified template DNA, 2 ì L MseI primer containing dNTP(Life Technologies), 0.5 ì L of IRD - labeled EcoRI primer (Li-Cor, Lincoln, NE, USA), 1.2 ì L of $10 \mathrm{X}$ PCR buffer plus $\mathrm{MgCl}_{2}$ (Applied Biosystems), and 0.06 ì L of AmpliTaq DNA Polymerase (Applied Biosystems). PCR amplifications consisted of one cycle of 30 seconds at $94^{\circ} \mathrm{C}, 30$ seconds at $65^{\circ} \mathrm{C}$, and 1 minute at $72^{\circ} \mathrm{C} ; 12$ cycles in which all denaturing and extending temperatures remained the same, and the annealing temperature was decreased by $0.7^{\circ} \mathrm{C}$ in each cycle; finally 23 cycles of 30 seconds at $94^{\circ} \mathrm{C}, 30$ seconds at $56^{\circ} \mathrm{C}$, and 1 minute at $72^{\circ} \mathrm{C}$ were performed.

\section{Detection and scoring of AFLP fragments}

After selective amplification, reactions were stopped with 5 ì $\mathrm{L}$ of gel loading buffer (consisting of $95 \%$ deionized formamide, $20 \mathrm{mM}$ EDTA $\mathrm{pH} 8.0$ and $1 \mathrm{mg} / \mathrm{mL}$ bromophenol blue). This mixture was heated at $94^{\circ} \mathrm{C}$ for 3 minutes, then quickly cooled on ice prior to

Table 2. Adapter and primer sequences $\left(5^{\prime}-3^{\prime}\right)$ used for amplified fragment length polymorphism (AFLP) analysis in Tuta absoluta.

\begin{tabular}{lll}
\hline Primer name & Primer type & Sequences $\left(5^{\prime}-3^{\prime}\right)$ \\
\hline Eco RI -A1 & Adapter & CTCGTAGACTGCGTACC \\
Eco RI -A2 & Adapter & AATTGGTACGCAGTCTAC \\
E0 & +0 & GACTGCGTACCAATTC \\
EACA & +3 & GACTGCGTACCAATTCACA \\
EACG & +3 & GACTGCGTACCAATTCACG \\
EACT & +3 & GACTGCGTACCAATTCACT \\
MseI - A1 & Adapter & GACGATGAGTCCTGAG \\
MseI - A2 & Adapter & TACTCAGGACTCAT \\
MC & +1 & GATGAGTCCTGAGTAAC \\
MCAC & +3 & GATGAGTCCTGAGTAACAC \\
MCAG & +3 & GATGAGTCCTGAGTAACAG \\
MCAT & +3 & GATGAGTCCTGAGTAACAT \\
MCTG & +3 & GATGAGTCCTGAGTAACTG \\
MCTT & +3 & GATGAGTCCTGAGTAACTT \\
\hline
\end{tabular}

gel loading. AFLP products were resolved on denaturing gels containing $6.5 \%$ polyacrylamide (Li-Cor), $7.5 \mathrm{M}$ urea, and $1 \mathrm{X}$ TBE ( $89 \mathrm{mM}$ TRIS, $89 \mathrm{mM}$ boric acid, and $2 \mathrm{mM}$ EDTA). A volume of 1.0 ì $\mathrm{L}$ of both sample and IRD-labeled size standards (outside wells) (Li-Cor) were loaded to individual wells of this gel. Electrophoresis was conducted on a Li-Cor 4200 automated sequencer using $1 \mathrm{X}$ TBE running buffer, with run parameters of $1,500 \mathrm{~V}, 40 \mathrm{~mA}, 40 \mathrm{~W}$, scan speed $4,50^{\circ} \mathrm{C}$ plate temperature, and 16 bit pixel depth for collection of TIFF image files.

Polymorphic fragments were scored using RFLPscan version 3.54 (Scanalytics). Automatic detection thresholds were set at the maximum level to minimize the number of automatically scored fragments, and polymorphic fragments were scored electronically. The software automatically assigns molecular weights to fragments and generates reports of fragment presence/ absence strings for each sample. As proposed by Vos et al. (1995), each set of at least 10 scored loci was defined as an AFLP fingerprint.

\section{Data analysis}

Genetic similarities among AFLP fingerprints from each population were estimated according to the formula of Dice (1945), $\mathrm{GS}_{(\mathrm{ij})}=2 \mathrm{a} /(2 \mathrm{a}+\mathrm{b}+\mathrm{c})$, where $\mathrm{GS}_{(\mathrm{ij})}$ is the genetic similarity between individuals $\mathrm{i}$ and $\mathrm{j}$; $a$ is the number of polymorphic bands that are shared by $i$ and $j$; $b$ is the number of bands present in $i$ and absent in $\mathrm{j}$; and $\mathrm{c}$ is the opposite of $\mathrm{b}$. Genetic relationships among AFLP fingerprints were represented in a dendrogram based on the unweighted pair-group method of arithmetic averages (UPGMA) with bootstrapping (500 replicates) and a principal coordinate analysis bidimensional scatter plot, respectively done by treecon for windows software package version 1.3b (Van de Peer \& De Wachter, 1994) and NTSYS-PC version 2.02k (Rohlf, 1997).

\section{Results and Discussion}

Seven primer combinations were used for the analysis of populations of T. absoluta. Considering these combinations, fifteen amplified loci were selected for which the most common allele in each population occurred at a frequency greater than or equal to $75 \%$, as suggested by McMichael \& Prowell (1999) (Table 3).

Twenty-eight different multilocus AFLP fingerprints were identified in the 32 T. absoluta sampled (Table 4). 
Table 3. Frequency of occurrence of most common allele on fifteen loci selected by amplified fragment length polymorphism (AFLP) technique for Tuta absoluta populations identification ${ }^{(1)}$.

\begin{tabular}{|c|c|c|c|c|c|c|c|c|}
\hline \multirow{2}{*}{$\begin{array}{c}\text { Primer pair } \\
\text { combinations (bp) }\end{array}$} & \multicolumn{8}{|c|}{ Frequency of most common allele ${ }^{(2)}$} \\
\hline & GO & PA & $\mathrm{PE}$ & S J & ST & SU & UB & $\mathrm{VC}$ \\
\hline 1. MCAC-EACT (73) & $1(1)$ & $1(1)$ & $1(1)$ & $1(1)$ & $1(0)$ & $1(0)$ & $1(1)$ & $1(1)$ \\
\hline 2. МСTT-EACT (135) & $1(0)$ & $0.75(1)$ & $0.75(1)$ & $1(0)$ & $0.75(1)$ & $1(1)$ & $1(1)$ & $1(1)$ \\
\hline 3. MCAT-EACA (174) & $1(0)$ & $1(0)$ & $1(0)$ & $1(1)$ & $1(0)$ & $0.75(0)$ & $0.75(1)$ & $0.75(1)$ \\
\hline 4. MCTG-EACA (189) & $1(0)$ & $0.75(1)$ & $0.75(1)$ & $0.75(1)$ & $0.75(1)$ & $0.75(1)$ & $0.75(1)$ & $1(0)$ \\
\hline 5. MCTG-EACA (206) & $1(0)$ & $1(1)$ & $0.75(0)$ & $0.75(1)$ & $0.75(0)$ & $1(1)$ & $1(1)$ & $1(1)$ \\
\hline 6. МСТT-ЕАСТ (209) & $1(0)$ & $1(0)$ & $1(1)$ & $0.75(1)$ & $1(1)$ & $0.75(1)$ & 0.75 & $1(1)$ \\
\hline 7. MCTT-EAGG (213) & $1(1)$ & $1(0)$ & $1(0)$ & $1(0)$ & 0.75 & $1(0)$ & $1(0)$ & $1(1)$ \\
\hline 8. MCAC-EAGG (219) & $1(0)$ & $1(0)$ & $1(0)$ & $1(1)$ & $0.75(0)$ & $1(0)$ & $1(0)$ & $1(0)$ \\
\hline 9. MCTG-EACA (242) & $1(0)$ & $0.75(1)$ & $1(1)$ & $0.75(0)$ & $1(1)$ & $1(1)$ & $1(1)$ & $0.75(0)$ \\
\hline 10. MCAC-EACT (266) & $1(1)$ & $1(0)$ & $1(0)$ & $1(0)$ & $1(1)$ & $0.75(0)$ & $1(0)$ & $1(1)$ \\
\hline 11. MCTT-EAGG (300) & $0.75(1)$ & $1(1)$ & $1(1)$ & $1(0)$ & $1(0)$ & $0.75(1)$ & $1(1)$ & $0.75(1)$ \\
\hline 12. МСТT-EACT (304) & $1(0)$ & $1(1)$ & $0.75(1)$ & $1(0)$ & $1(0)$ & $1(0)$ & $1(0)$ & $1(0)$ \\
\hline 13. MCAT-EAGG (339) & $0.75(0)$ & $0.75(0)$ & 0.75 & $0.75(1)$ & $1(0)$ & $0.75(0)$ & $1(1)$ & $1(0)$ \\
\hline 14. MCAC-EACT (391) & $1(1)$ & $1(0)$ & $1(0)$ & $1(0)$ & $1(1)$ & $1(0)$ & $1(0)$ & $1(1)$ \\
\hline 15. MCAT-EACA (426) & $1(0)$ & $1(0)$ & $1(0)$ & $1(1)$ & $1(0)$ & $1(0)$ & $1(0)$ & $1(0)$ \\
\hline
\end{tabular}

${ }^{(1)}$ Numbers inside the brackets show the status of the character absent $(0)$ or present $(1) .{ }^{(2)}$ GO: Goianápolis; PA: Paulínia; PE: Camocim de São Félix; SJ: São João da Barra; ST: Santa Tereza; SU: Sumaré; UB: Uberlândia; VC: Viçosa.

Table 4. Presence (1) or absence (0) of amplified fragment length polymorphism (AFLP) fingerprints in Tuta absoluta.

\begin{tabular}{|c|c|c|c|c|c|c|c|c|c|c|c|c|c|c|c|}
\hline \multirow{2}{*}{ Fingerprint $^{(1)}$} & \multicolumn{15}{|c|}{ AFLP loci } \\
\hline & 1 & 2 & 3 & 4 & 5 & 6 & 7 & 8 & 9 & 10 & 11 & 12 & 13 & 14 & 15 \\
\hline$\overline{\mathrm{GO} 1}$ & 1 & 0 & 0 & 0 & 0 & 0 & 1 & 0 & 0 & 1 & 1 & 0 & 1 & 1 & 1 \\
\hline $\mathrm{GO} 2$ & 1 & 0 & 0 & 0 & 0 & 0 & 1 & 0 & 0 & 1 & 0 & 0 & 0 & 1 & 1 \\
\hline GO3 & 1 & 0 & 0 & 0 & 0 & 0 & 1 & 0 & 0 & 1 & 1 & 0 & 0 & 1 & 1 \\
\hline PA1 & 1 & 0 & 0 & 1 & 1 & 0 & 0 & 0 & 1 & 0 & 1 & 1 & 0 & 0 & 0 \\
\hline PA2 & 1 & 1 & 0 & 0 & 1 & 0 & 0 & 0 & 1 & 0 & 1 & 1 & 0 & 0 & 0 \\
\hline PA3 & 1 & 1 & 0 & 1 & 1 & 0 & 0 & 0 & 0 & 0 & 1 & 1 & 0 & 0 & 0 \\
\hline PA4 & 1 & 1 & 0 & 1 & 1 & 0 & 0 & 0 & 1 & 0 & 1 & 1 & 1 & 0 & 0 \\
\hline PE1 & 1 & 0 & 0 & 1 & 1 & 1 & 0 & 0 & 1 & 0 & 1 & 0 & 1 & 0 & 0 \\
\hline PE2 & 1 & 1 & 0 & 0 & 0 & 1 & 0 & 0 & 1 & 0 & 1 & 1 & 0 & 0 & 0 \\
\hline PE3 & 1 & 1 & 0 & 1 & 0 & 1 & 0 & 0 & 1 & 0 & 1 & 1 & 1 & 0 & 0 \\
\hline SJ1 & 1 & 0 & 1 & 1 & 1 & 1 & 0 & 1 & 0 & 0 & 0 & 0 & 0 & 0 & 0 \\
\hline SJ2 & 1 & 0 & 1 & 1 & 1 & 1 & 0 & 1 & 0 & 0 & 0 & 0 & 1 & 0 & 0 \\
\hline SJ3 & 1 & 0 & 1 & 0 & 0 & 0 & 0 & 1 & 1 & 0 & 0 & 0 & 1 & 0 & 0 \\
\hline ST1 & 0 & 1 & 0 & 1 & 0 & 1 & 1 & 1 & 1 & 1 & 0 & 0 & 0 & 1 & 1 \\
\hline ST2 & 0 & 0 & 0 & 1 & 0 & 1 & 1 & 0 & 1 & 1 & 0 & 0 & 0 & 1 & 1 \\
\hline ST3 & 0 & 1 & 0 & 1 & 0 & 1 & 1 & 0 & 1 & 1 & 0 & 0 & 0 & 1 & 1 \\
\hline ST4 & 0 & 1 & 0 & 0 & 1 & 1 & 0 & 0 & 1 & 1 & 0 & 0 & 0 & 1 & 1 \\
\hline SU1 & 0 & 1 & 0 & 1 & 1 & 1 & 0 & 0 & 1 & 0 & 1 & 0 & 0 & 0 & 0 \\
\hline SU2 & 0 & 1 & 0 & 0 & 1 & 1 & 0 & 0 & 1 & 1 & 1 & 0 & 0 & 0 & 0 \\
\hline SU3 & 0 & 1 & 0 & 1 & 1 & 1 & 0 & 0 & 1 & 0 & 1 & 0 & 1 & 0 & 0 \\
\hline SU4 & 0 & 1 & 1 & 1 & 1 & 0 & 0 & 0 & 1 & 0 & 0 & 0 & 0 & 0 & 0 \\
\hline UB1 & 1 & 1 & 1 & 1 & 1 & 0 & 0 & 0 & 1 & 0 & 1 & 0 & 1 & 0 & 0 \\
\hline UB2 & 1 & 1 & 1 & 1 & 1 & 1 & 0 & 0 & 1 & 0 & 1 & 0 & 1 & 0 & 0 \\
\hline UB3 & 1 & 1 & 0 & 1 & 1 & 1 & 0 & 0 & 1 & 0 & 1 & 0 & 1 & 0 & 0 \\
\hline UB4 & 1 & 1 & 1 & 0 & 1 & 1 & 0 & 0 & 1 & 0 & 1 & 0 & 1 & 0 & 0 \\
\hline $\mathrm{VC} 1$ & 1 & 1 & 0 & 0 & 1 & 1 & 1 & 0 & 1 & 1 & 1 & 0 & 0 & 1 & 1 \\
\hline $\mathrm{VC} 2$ & 1 & 1 & 1 & 0 & 1 & 1 & 1 & 0 & 0 & 1 & 1 & 0 & 0 & 1 & 1 \\
\hline $\mathrm{VC} 3$ & 1 & 1 & 1 & 0 & 1 & 1 & 1 & 0 & 0 & 1 & 0 & 0 & 0 & 1 & 1 \\
\hline
\end{tabular}

Two different groups of fingerprint numbers were observed, i.e., three band patterns (fingerprints) on larvae from Goianápolis $\left(\mathrm{GO}_{1 \text { to } 3}\right)$, Camocim de São Félix ( $\mathrm{PE}_{1}$ to 3$)$, São João da Barra ( $\mathrm{SJ}_{1}$ to 3 ), and Viçosa ( $\mathrm{VC}_{1}$ to 3$)$; and four band patterns from Paulínea $\left(\mathrm{PA}_{1}\right.$ to 4$)$, Santa Tereza
( $\left.\mathrm{ST}_{1 \text { to }}{ }_{4}\right)$, Sumaré (SU $\mathrm{SU}_{1}$ to $)$, and Uberlândia $\left(\mathrm{UB}_{1 \text { to } 4}\right)$.

The dendrogram, based on unweigthed pair-group method, separated the AFLP fingerprints in two distinct groups (Figure 1). The first (group A) was composed by multilocus data of larvae from Camocim de São Félix, Paulínea, São João da Barra, Sumaré, and Uberlândia. The second group was formed by fingerprints from Goianápolis, Santa Tereza, and Viçosa. Although bootstrap values showed limited support for some nodes, the same type of cluster was observed (Figure 2).

The results of this work partially corroborated previous information (Siqueira et al., 2000b) regarding genetic differences related to insecticide resistance among T. absoluta populations. The separation of 28 AFLP fingerprints of this insect, in two distinct groups, was supported not only by UPGMA bootstrap analysis but also by principal coordinate analysis. According to Siqueira et al. (2000a, 2000b), tomato leafminer larvae from Paulínia, São João da Barra, and Uberlândia (Figure 1) were more susceptible to abamectin than populations from Viçosa, Lavras, and Araguari. These studies indicated differences in the resistance levels among different populations for each tested insecticide. Such variability suggests differential selection pressures, genetic diversity in the resistance mechanisms among the insect populations, or both (Kerns \& Gaylor, 1992). This fact could explain the formation of different groups (A and B) of T. absoluta populations used in the present work.

The accumulated variance of the first three eigenvalues, generated by the principal coordinate analysis was greater than sixty percent. As suggested 


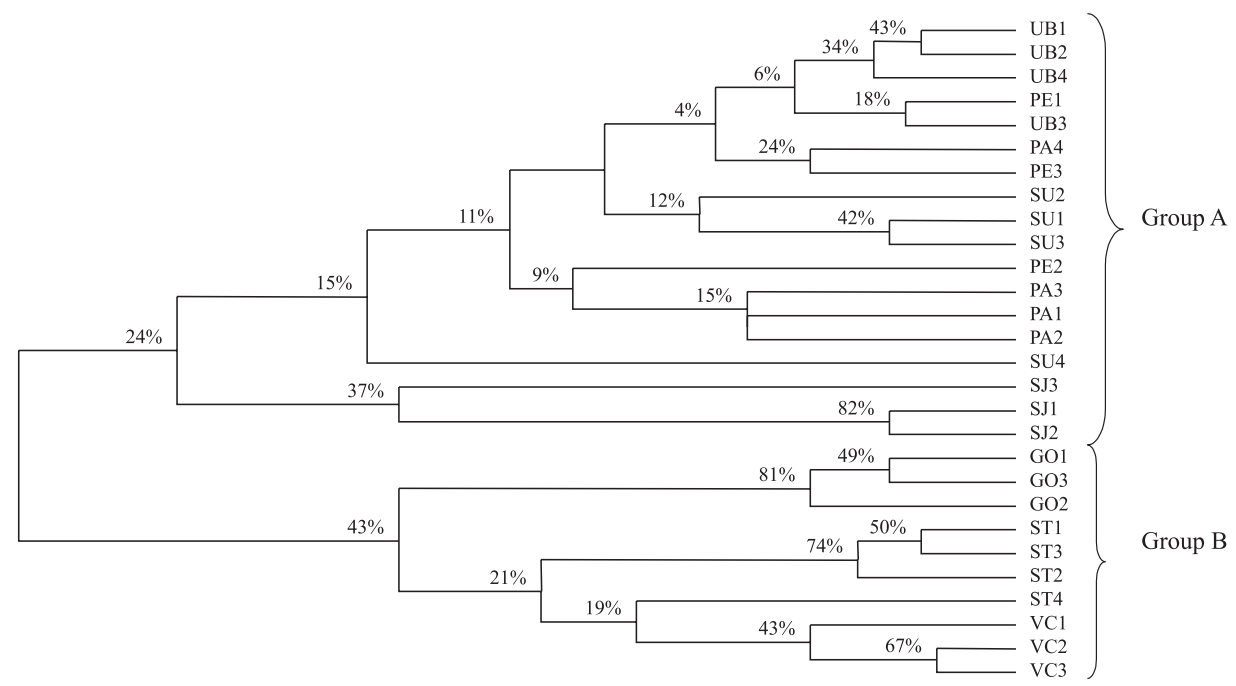

Figure 1. Dendrogram of eight populations of Tuta absoluta amplified fragment length polymorphism (AFLP) fingerprints resulting from unweighted pair group method (UPGMA) with cluster analysis. Bootstrap support (percent of 500 replicates) is indicated for each branch. $\mathrm{GO}_{1 \text { to }}$ : three fingerprints from Goianápolis; $\mathrm{PE}_{1 \text { to }}$ : three fingerprints from Camocim de São Félix; $\mathrm{SJ}_{1}$ to 3 : three fingerprints from São João da Barra; $\mathrm{VC}_{1}$ to 3 : three fingerprints from Viçosa; $\mathrm{PA}_{1 \text { to }}$ : four fingerprints from Paulínia; $\mathrm{ST}_{1 \text { to } 4}$ : four fingerprints from Santa Tereza; $\mathrm{SU}_{1 \text { to } 4}$ : four fingerprints from Sumaré; $\mathrm{UB}_{1}$ to 4 : four fingerprints from Uberlândia.

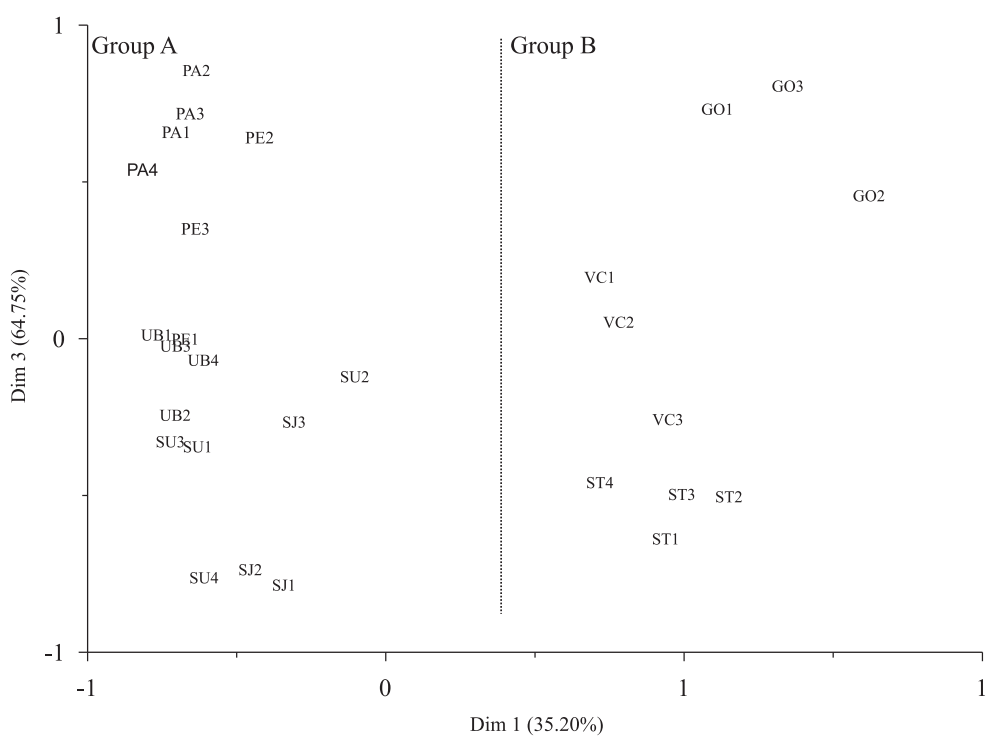

Figure 2. Scatter plot of principal coordinate analysis of 28 amplified fragment length polymorphism (AFLP) fingerprints of Tuta absoluta. Numbers in the parenthesis, located in the $\mathrm{X}$ and $\mathrm{Y}$ axis, indicate cumulative percentages of the eigenvalues. Group $\mathrm{A}: \mathrm{PE}_{1 \text { to } 3}$ : three fingerprints from Camocim de São Félix; $\mathrm{SJ}_{1 \text { to } 3}$ : three fingerprints from São João da Barra; $\mathrm{PA}_{1}$ to 4 : four fingerprints from Paulínia; $\mathrm{SU}_{1 \text { to } 4}$ : four fingerprints from Sumaré; $\mathrm{UB}_{1 \text { to } 4}$ : four fingerprints from Uberlândia. Group B: $\mathrm{GO}_{1 \text { to } 3}$ : three fingerprints from Goianápolis; $\mathrm{VC}_{1}$ to 3 : three fingerprints from Viçosa; $\mathrm{ST}_{1 \text { to } 4}$ : four fingerprints from Santa Tereza. 
by Sparks et al. (1999), when the accumulated variance of the first three eigenvalues are greater than $60 \%$, it is reasonable to study the characteristics (in this case population divergence) in a bidimensional space rather than an n-dimensional one. In this work, the first and the third coordinate axes were plotted in order to show the best dispersion of these fingerprints. The same trend displayed on the UPGMA dendrogram (Figure 1) was observed in the plot of the two principal coordinate axes (Figure 2), that is, the division of twenty-eight AFLP fingerprints into two groups described.

The differential selection pressures could be obtained by using different compounds, over-recommended insecticide dosages, as well as frequency of application. Even though the insecticide registration in Brazil is a national policy (Andrei, 1999), there is a variation in the acceptance or usage of a particular product in a specific region (Guedes et al., 1995). For example, in the region of Goianápolis, despite the low efficiency in controlling T. absoluta, farmers continuously spray methamidophos against this pest. As a result of this practice, failure in control is detected and an increase of the insecticide dosage or a raise in the frequency of applications is often observed (Picanço et al., 1995). In this case, agricultural practices are promoting the selection of resistant individuals of $T$. absoluta to insecticides, but with different - morphological, physiological and ecological - characteristics depending on the origin of the insects, and in part explaining the results found in this work.

Besides the effects of the insecticides on T. absoluta strains, alternative hosts could generate differential preferences for acceptance between/within population(s) (Jaenike, 1990). Genetic based differences in host acceptance have been found between US mainland and Virgin Island populations of Halitosis viruses (Lepidoptera: Noctuidae) (Schneider \& Roush, 1986; Waldvogel \& Gould, 1990). Additionally, Moreira et al. (2001) working with populations of T. absoluta from Camocim de São Félix, Santa Tereza, Uberlândia, and Viçosa observed differences on biological characteristics of this insect when feeding on several wild tomato species. The authors also proposed the division of these populations in two groups, i.e., Santa Tereza and Uberlândia, presented in group B and A, respectively, in order to obtain a core collection of this insect. All of these results could support the results found in this work.

\section{Conclusions}

1. AFLP technique demonstrates usefulness in the study of geographical variation of $T$. absoluta populations.
2. The results obtained can be used to explain or to detect the differences in the populations responses to insecticides, as well as host plants.

3. Data obtained can also be used in the breeding programs for tomato resistance to T. absoluta, supporting the usage of one representative population, depending on the site of plant selection.

\section{References}

ANDREI, E. Compêndio de defensivos agrícolas. São Paulo: Andrei, 1999. 672p.

CERVERA, M.T.; CABEZAS, J.A.; SIMÓN, B.; MARTÍNEZZAPATER, J.M.; BEITIA, F.; CENIS, J.L. Genetic relationships among biotypes of Bemisia tabaci (Hemiptera: Aleyrodidae) based on AFLP analysis. Bulletin of Entomological Research, v.90, p.301-306, 2000.

DICE, L.R. Measures of the amount of ecological association between species. Ecology, v.26, p.297-302, 1945.

GUEDES, R.N.C.; PICANÇO, M.C.; GUEDES, N.M.P.; MADEIRA, N.R. Sinergismo do óleo mineral sobre a toxicidade de inseticidas para Scrobipalpuloides absoluta (Lepidoptera: Gelechiidae). Pesquisa Agropecuária Brasileira, v.30, p.313-318, 1995.

GUEDES, R.N.C.; PICANÇO, M.C.; MATIOLI, A.L.; ROCHA, D.M. Efeito de inseticidas e sistemas de condução do tomateiro no controle de Scrobipalpuloides absoluta (Meyrick) (Lepidoptera: Gelechiidae). Anais da Sociedade Entomológica do Brasil, v.23, p.321-325, 1994.

JAENIKE, J. Host specialization in phytophagous insects. Annual Review of Ecology and Systematics, v.21, p.243-273, 1990.

KERNS, D.L.; GAYLOR, M.J. Insecticide resistance in field populations of the cotton aphid (Homoptera: Aphididae). Journal of Economic Entomology, v.85, p.1-8, 1992.

McMICHAEL, M.; PROWELL, D.P. Differences in amplified fragment-length polymorphisms in fall armyworm (Lepidoptera: Noctuidae) host strains. Annals of the Entomological Society of America, v.92, p.175-181, 1999.

MOREIRA, G.R.; SILVA, D.J.H.; PICANÇO, M.C.; PETERNELLI, L.A.; CASALI, V.W.D. Diversidade genética de Tuta absoluta (Meyrick) (Lepidoptera: Gelechiidae) em Lycopersicon spp. Horticultura Brasileira, v.19, p.201-205, 2001.

PARSONS, Y.M.; SHAW, K.L. Species boundaries and genetic diversity among Hawaiian crickets of the genus Laupala identified using amplified fragment length polymorphism. Molecular Ecology, v.10, p.1765-1772, 2001.

PICANÇO, M.C.; FALEIRO, F.G.; PALLINI FILHO, A.; MATIOLI, A.L. Perdas na produtividade do tomateiro em sistemas alternativos de controle fitossanitário. Horticultura Brasileira, v.15, p.88-91, 1997.

PICANÇO, M.C.; LEITE, G.L.D.; GUEDES, R.N.C.; SILVA, E.A. Yield loss in trellised tomato affected by insecticidal sprays and planting spacing. Crop Protection, v.17, p.447-452, 1998. 
PICANÇO, M.C.; SILVA, D.J.H. da; LEITE, G.L.D.; MATA, A.C. da; JAM, G.N. Intensidade de ataque de Scrobipalpula absoluta (Meyrick, 1917) (Lepidoptera: Gelechiidae) ao dossel de três espécies de tomateiro. Pesquisa Agropecuária Brasileira, v.30, p.429-433, 1995.

REINEKE, A.; KARLOVSKY, P.; ZEBITZ, C.P.W. Amplified fragment length polymorphism analysis of different geographic populations of gypsy moth, Lymantria dispar (Lepidoptera: Lymantriidae). Bulletin of Entomological Research, v.89, p.7988, 1999.

REINEKE, A.; KARLOVSKY, P.; ZEBITZ, C.P.W. Preparation and purification of DNA from insects for AFLP analysis. Insect Molecular Biology, v.7, p.95-99, 1998.

ROHLF, F.J. NTSYS-PC: numerical taxonomy and multivariate analysis system: version 2.0. New York: Exeter Software, 1997. $37 \mathrm{p}$.

SALAZAR, E.S.; ARAYA, J.E. Detección de resistencia a insecticidas en la polilla del tomate. Simiente, v.67, p.8-22, 1997.

SCHNEIDER, J.C.; ROUSH, R.T. Genetic differences in oviposition preference between two populations of Heliothis virescens. In: HUETTEL, D. (Ed.). Evolutionary genetics of invertebrate behavior. New York: Plenum, 1986. p.163-171.

SHIPP, J.L.; WANG, K.; FERGUSON, G. Evaluation of commercially produced Trichogramma spp. (Hymenoptera: Trichogrammatidae) for control of tomato pinworm Keiferia lycopersicella (Lepidoptera: Gelechiidae) on greenhouse tomatoes. Canadian Entomologist, v.130, p.721-731, 1998.

SIQUEIRA, H.A.A.; GUEDES, R.N.C.; PICANÇO, M.C. Cartap resistance and synergism in populations of Tuta absoluta (Lep., Gelechiidae). Journal of Applied Entomology, v.124, p.233-238, 2000a.

SIQUEIRA, H.A.A.; GUEDES, R.N.C.; PICANÇO, M.C. Insecticide resistance in populations of Tuta absoluta (Lepidoptera: Gelechiidae). Agricultural and Forest Entomology, v.2, 147-153, 2000b.

SPARKS, T.H.; SCOTT, W.A.; CLARKE, R.T. Traditional multivariate techniques: potential for use in ecotoxicology. Environmental Toxicology and Chemistry, v.18, p.128-137, 1999.

VAN DE PEER, Y.; DE WACHTER, R. TREECON for Windows: a software package for the construction and drawing of evolutionary trees for the Microsoft Windows environment. Computer Applications in the Biosciences, v.10, p.569-570, 1994.

VOS, P.; HOGERS, R.; BLEEKER, M.; REIJANS, M.; LEE, van de T.; HORNES, M.; FRIJTERS, A.; POT, J.; PELEMAN, J.; KUIPER, M.; ZABEAU, M. AFLP: a new technique for DNA fingerprinting. Nucleic Acids Research, v.23, p.4407-4414, 1995.

WALDVOGEL, M.; GOULD, F. Variation in oviposition preference between strains of Heliothis virescens. Evolution, v.44, p.13261337, 1990.

Received on March 14, 2003 e accepted on April 6, 2004 